\title{
TECHNOLOGICAL FEATURES OF HIGH-SULFUR HEAVY CRUDE OILS PROCESSING
}

\author{
Petro Topilnytskyy ${ }^{1} \otimes$, Sergii Paiuk ${ }^{2}$, Halyna Stebelska ${ }^{2}$, \\ Viktoria Romanchuk ${ }^{1}$, Tetiana Yarmola ${ }^{1}$
}

https://doi.org/10.23939/chcht13.04.503

\begin{abstract}
Crude oils of the Yablunivsky deposit (Poltava region, Ukraine) have been studied in order to choose further ways of their processing. The fractional composition was studied by the method of simulated distillation. The structural and mechanical properties of petroleum products, the content of metals and the elemental composition were determined. Studies have shown that oils are of high-sulfur heavy grade, without light distillates; they have high density, viscosity, and large amounts of metals. A flow chart for the processing of such oils has been proposed.
\end{abstract}

Keywords: heavy oil, physico-chemical properties, rheological properties.

\section{Introduction}

The production of gasoline, jet fuels, diesel fuels, fuel oils, and even bitumen is primarily determined by the fractional composition, chemical and elemental composition of crude oil. The conditions of exploitation, storage, and transportation of the obtained petroleum products are determined by the presence of various hydrocarbon groups, their viscous-temperature and lowtemperature properties. The Ukrainian oil refining industry has not yet processed heavy crude oils. The production of such oils is no more than $1-2 \%$ of the total oil production in Ukraine. In view of the acute deficit of domestic petroleum products, it is extremely important and relevant to search and study heavy crude oils.

Reserves of heavy oils significantly exceed those of light and low-viscous oils, and, according to experts, they range from 650 billion to 1 trillion tons [1]. It is almost five times higher than reserves of low- and medium-viscous oils, which are only 162.3 billion tons.

\footnotetext{
${ }^{1}$ Lviv Polytechnic National University

12, S.Bandery St., 79013 Lviv, Ukraine

${ }^{2}$ Geology Department, JSC Ukrgasvydobuvannia

$\triangle$ petro.i.topilnytskyi@lpnu.ua

(C) Topilnytskyi P., Paiuk S., Stebelska H., Romanchuk V., Yarmola T, 2019
}

The world distribution of heavy crude oils shows that more than $80 \%$ of the global reserves are located in South and North America, with a large share in Eastern Europe and Asia [2]. The largest reserves are in Canada (approximately 522.5 billion tons) and Venezuela (177.9 billion tons). Significant reserves are in Mexico, the United States, Russia, Kuwait, China and Norway [3-5]. Industrialized countries consider highly viscous oils as the main base for the coming years [6].

Heavy crude oils and natural bitumen are characterized by high content of aromatic hydrocarbons, resinous asphaltenes, high concentrations of metals and sulfur compounds, high density and viscosity, and high coke content. This leads to the increase in production cost, cost for transportation by existing oil pipelines and the difficulty of refining according to classical schemes. The production of highly viscous oils through traditional technologies leads to low yields of the resulting products and the loss of valuable associated components, resulting in a loss of profit and environmental damage. Sometimes, special pipelines with heating are built for the transport of heavy oils, which also increases the cost of production [7].

Ukrainian refineries are not intended for the processing of heavy oils. Some oils can be traditionally processed as a mixture with conventional light crude oil, but some of them need specialized plants, producing a limited range of petroleum products. Solving this problem is complicated by the fact that the data on heavy oils properties and composition are very incomplete, contradictory and disembodied. Lack of information makes it difficult to attract new investors.

Ukraine has all geological preconditions for the accumulation of heavy oils and bitumen deposits. The more prospective deposits are found in the northwest of the Dnipro-Donetsk depression (Bakhmacke, Tvanke, Kholmske deposits of heavy oil, maltha and asphalt), slopes of the Voronezh massif and the Ukrainian shield. Moreover, there are all grounds (by analogy with the geologically close West Canada) to expect the opening of significant oil-bitumen deposits within the large VolynPodilsky prospective oil and gas bearing area. According 
to the most conservative estimates, at least 2 billion tons of heavy oil and bitumen are concentrated in Ukraine and this value may increase significantly [8].

Some heavy oil reservoirs are found in the DniproDonetsk depression. They were not taken into account when reserve volume was calculated, though there are large deposits among them, e.g. Yablunivsky gas condensate field. Successful experience in developing this deposit proves the expediency of its "addition" to the general volume of oil, gas and condensate production. At present, the explored oil reservoirs of the Yablunivsky deposit is about 50 million tons. It is expected that the deposit contains highly viscous crude oil and natural bitumen, which are difficult or even impossible to be recovered by traditional methods, since they have properties of non-Newtonian fluids. The absence of the minimum required characteristics of heavy oil makes it impossible to select the optimal method for the exploration of the deposit, wells operation and ways of the most rational treatment.

Therefore, the aim of this work is to study the physico-chemical properties of heavy oils as well as their comparison with traditional oils of the East Ukrainian deposits.

\section{Experimental}

Several samples were withdrawn from different wells of Yablunivsky deposit (Poltava region, Ukraine):

Sample 1 with the density of $959 \mathrm{~kg} / \mathrm{m}^{3}$ at $323 \mathrm{~K}$ (oil well 88);

Sample 2 with the density of $969 \mathrm{~kg} / \mathrm{m}^{3}$ at $323 \mathrm{~K}$ (oil well 94);

Sample 3 with the density of $953 \mathrm{~kg} / \mathrm{m}^{3}$ at $323 \mathrm{~K}$ (oil well 337).

Sample 4 with the density of $823 \mathrm{~kg} / \mathrm{m}^{3}$ at $323 \mathrm{~K}$ (oils mixture of East-Ukrainian deposits, which is processed at PJSC "Ukrtatnafta" (Kremenchuk, Ukraine)), was taken for the comparison.

Oil density, content of chloride salts, water and sulfur were determined by standard methods [9-13].

Oils were distilled using simulated distillation, which is analogous to ASTM D2887, ASTM D5307 and ASTM D6352 [14-16]. The essence of the method is the chromatographic separation of oil and product hydrocarbons on a high-performance capillary column, followed by the registration of peaks by a flame-ionization detector. The gas chromatograph NR 7890 with flame ionization detector and Simdis software were used [17].

The determination of carbon and hydrogen was carried out by Liebig-Pregl method, nitrogen - by Dumas method, sulfur - by the combustion method [18]. The oxygen content was determined as the difference between $100 \%$ and the sum of other elements.

The kinematic viscosity, which is one of the main characteristics [19], was determined according to the standard [20].

Since the studied oils are highly viscous and fastfreezing ones, it is difficult to pipe them at low temperatures $[21,22]$. Hence, it was necessary to study their structural and mechanical characteristics. For this purpose, the Rheomat-30 viscometer (Contraves AG, Switzerland) with a rotational type coaxial cylinder in the gradient range of $0-452 \mathrm{~s}^{-1}$ was used. Measuring system CM409.484 consists of a cylinder with the diameter of $25 \mathrm{~mm}$ and chamber with the diameter of $23.8 \mathrm{~mm}$ and total volume of $40 \mathrm{~cm}^{3}$ in the temperature range from 293 to $343 \mathrm{~K}$. The required temperature was provided by the UH-8 circulation thermostat MLW (Germany), equipped with a special passive cell. Demineralized water was used as a heat carrier. The essence of the method is to register the antitorque moment of the inner cone of the measuring device with the material under study at different gradients of the deformation velocity with the subsequent calculation of the displacement stress and dynamic (effective) viscosity. Dynamic (effective) viscosity ( $\eta$, $\mathrm{Pa} \cdot \mathrm{s})$ was determined by the formula:

$$
\eta=\eta_{\text {rep }} \cdot \alpha
$$

where $\eta_{\text {rep }}$ is the viscosity corresponding to the position of the device switch at the strain tension for the corresponding measuring system, $\mathrm{Pa} \cdot \mathrm{s} ; \alpha$ is a device indication, $\%$.

The content of metals (iron, vanadium, nickel, chromium and other elements) in crude oil was determined on the spectrometer SERP-01. The identification of the elements is based on individual energy spectrum for each chemical element.

\section{Results and Discussion}

The results on density investigation in the temperature range of 383-293 K are represented in Fig. 1.

All three samples of crude oil can be characterized as extra heavy oil (density at $323 \mathrm{~K}$ is $953-969 \mathrm{~kg} / \mathrm{m}^{3}$ ). It is by $140-150 \mathrm{~kg} / \mathrm{m}^{3}$ higher than the density of Sample 4 . With the increase in temperature from 293 to $383 \mathrm{~K}$, the density of oil decreases by approx. 50 points.

The results of oils simulated distillation and elemental composition are presented in Tables 1 and 2, respectively.

The analysis of the fractional composition showed that the studied samples are abnormal; there are no gasoline fractions in them, and the beginning of boiling is $498-503 \mathrm{~K}$. The content of diesel fuel fractions is only 
$20 \%$, which is much smaller than in the mixture of EastUkrainian oils. The content of fractions boiling at the temperature above $773 \mathrm{~K}$ is $54-58 \%$. This complicates the rectification process with a deeper selection of distillates. Specialized equipment necessary for narrow fractions selection should be used to provide the strict conditions of distillation: a deeper vacuum in the system and a high temperature in the cube [23].

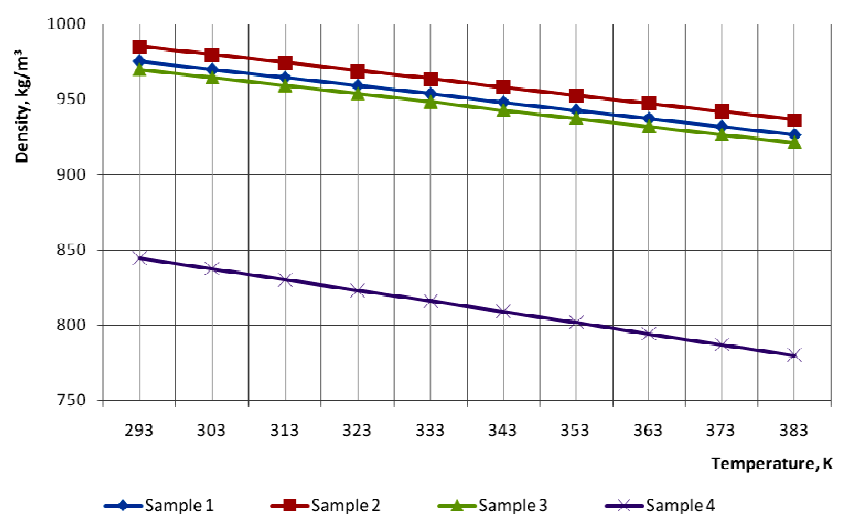

Fig. 1. Density of Samples 1-4 vs. temperature
In the investigated samples the amount of carbon $(82.9-83.2 \mathrm{wt} \%)$ is by approx. $3 \%$ higher, and hydrogen amount $(11.9-12.3 \mathrm{wt} \%)$ is proportional to the values obtained for the mixture of East-Ukrainian oils. Investigated oil is 2 times more oxygen rich. Typically, nitrogen compounds are contained in crude oil in relatively small amounts - about ten or even hundredths of a percent. High nitrogen content is characteristic of heavy oils. The content of nitrogen is an important value because of its harmful effects on reforming and cracking catalysts. For Samples 1-3 the nitrogen content is 11-15 times higher as compared with that for Sample 4. Sulfur is the most common of heteroatoms in oil and petroleum products. Its content in crude oil varies from hundredths of a percent to even $14 \%$. Determination of sulfur in oil and its removal is of great importance, since sulfur compounds have a negative effect on the quality of petroleum products, poison expensive catalysts of oil refining, pollute the environment during combustion, and cause corrosion of equipment [24]. In the oils of the Yablunivsky deposit, the sulfur content is $2.9-3.1 \%$, which exceeds the sulfur content in the mixture of EastUkrainian oils by 3.5-3.8 times.

Table 1

Fractional composition of oils

\begin{tabular}{|c|c|c|c|c|}
\hline Fractional composition & Sample 1 & Sample 2 & Sample 3 & Sample 4 \\
\hline $5 \%$ boiled at, $\mathrm{K}$ & 503 & 503 & 498 & 348 \\
\hline $10 \%$ boiled at, $\mathrm{K}$ & 553 & 553 & 548 & 364 \\
\hline $15 \%$ boiled at, $\mathrm{K}$ & 589 & 587 & 587 & 381 \\
\hline $20 \%$ boiled at, $\mathrm{K}$ & 625 & 620 & 623 & 403 \\
\hline $25 \%$ boiled at, $\mathrm{K}$ & 658 & 652 & 659 & 428 \\
\hline $30 \%$ boiled at, $\mathrm{K}$ & 696 & 677 & 697 & 461 \\
\hline $35 \%$ boiled at, $\mathrm{K}$ & 720 & 699 & 722 & 488 \\
\hline $40 \%$ boiled at, $\mathrm{K}$ & 759 & 722 & 763 & 518 \\
\hline $45 \%$ boiled at, $\mathrm{K}$ & 797 & 766 & 800 & 548 \\
\hline $50 \%$ boiled at, $\mathrm{K}$ & - & 809 & - & 578 \\
\hline End boiling point, $\mathrm{K}$ & 813 & 813 & 813 & 813 \\
\hline Yield to $342 \mathrm{~K}, \%$ & 0.2 & 0.2 & 0.2 & 1.7 \\
\hline Yield to $473 \mathrm{~K}, \%$ & 3.0 & 3.0 & 3.0 & 32.5 \\
\hline Yield to $633 \mathrm{~K}, \%$ & 21.0 & 22.0 & 21.0 & 59.0 \\
\hline Yield to $773 \mathrm{~K}, \%$ & 58.0 & 54.0 & 58.0 & 79.0 \\
\hline Yield to $813 \mathrm{~K}, \%$ & 46.6 & 50.3 & 46.1 & 83.5 \\
\hline
\end{tabular}

Table 2

Elemental composition of oils

\begin{tabular}{|c|c|c|c|c|c|}
\hline \multirow{2}{*}{ Samples } & \multicolumn{5}{|c|}{ Content, wt \% } \\
\hline & Carbon & Hydrogen & Oxygen & Nitrogen & Sulfur \\
\hline Sample 1 & 83.2 & 11.9 & 1.0 & 1.1 & 2.8 \\
\hline Sample 2 & 82.5 & 12.3 & 1.1 & 1.2 & 2.9 \\
\hline Sample 3 & 82.9 & 12.3 & 0.9 & 0.8 & 3.1 \\
\hline Sample 4 & 85.8 & 12.8 & 0.53 & 0.07 & 0.8 \\
\hline
\end{tabular}


Analyzing the data presented in Fig. 1 and Tables 1,2 , we may assert that according to the classification on the physico-chemical characteristics the investigated oils are extra heavy, high-sulfur (sulfur content is about $3 \%$ ) oils with low content of light fractions $(<25 \%)$. Taking into account the density and fractional composition of the fractions boiled to $633 \mathrm{~K}$, these fractions may contain alkanes (from tridecane $\mathrm{CH}_{3}-\left(\mathrm{CH}_{2}\right)_{12}-\mathrm{CH}_{3}$ to heneicosane $\left.\mathrm{CH}_{3}-\left(\mathrm{CH}_{2}\right)_{19}-\mathrm{CH}_{3}\right)$, and in fuel oils from docazane $\mathrm{CH}_{3}-\left(\mathrm{CH}_{2}\right)_{20}-\mathrm{CH}_{3}$ to pentatriacontane $\left.\mathrm{CH}_{3}-\left(\mathrm{CH}_{2}\right)_{33}-\mathrm{CH}_{3}\right)$, cycloalkanes (from pentacyclohexane and higher), arenes (acenaphthenes, fluorenes, anthracenes, phenatrens); the fractions $>633 \mathrm{~K}$ contains pyrenes, chrysenes, 1,2-benzanthracene, 3,4-benzenfenanthracene [5].

Since Samples 1-3 contain a significant number of fractions boiled above $813 \mathrm{~K}$, the content of bicyclic, tricyclic and polycyclic hydrocarbons is significant.

Taking into account that all fractions of Samples 13 are boiled at the temperatures above $500 \mathrm{~K}$, mercaptans are absent in oils, the sulfides can be represented by diaryl sulfides, thiacyclans and arylthiaalkanes. Cycloalkyl derivatives of benzene and dibenzothiophene are main components of the high boiling fractions. Nitrous compounds can be represented by acridins, indoles and carbazols.

The content of metals in oils is presented in Table 3 . The vanadium content is of special attention because recently there is a significant increase in demand for vanadium. The reasons are the following:

- the general growth of world steel production; the addition of tenths and hundredths of a percent of vana- dium increases the strength of steel by $25 \%$, and durability of products based on them - by 1.5 times;

- the advanced growth of structural, stainless and special steels production, especially in China;

- the production of special alloys for jet engines, rocket, spacecraft and submarines frames;

- the use of vanadium in the manufacture of batteries (it is included in the lithium polymer battery);

- the use of vanadium-based alloys as superconducting material;

- use of vanadium to produce catalysts;

- the rapid growth of prices for a number of steel ligatures (primarily nickel) and the search for their substitutes.

In addition, vanadium and nickel have a negative effect on the catalysts used in their processing, which creates great difficulties in the process of cracking, pyrolysis, and others. During the combustion of fuel oils, the vanadium oxide is formed, which strongly corrodes the fuel equipment and poisons the environment. Vanadium in oil is in the form of vanadyl porphyrins. The amount of vanadium is in relation with the amount of sulfurous compounds, because it contributes to the reduction of sulfates to hydrogen sulfide and free sulfur.

Oils of the Yablunivsky deposit are vanadium-type oils, since the ratio $\mathrm{V} / \mathrm{Ni}>1$. Such type of oil is of industrial value for the extraction of vanadium. The resource potential of heavy vanadium oils can be a reliable source of support for the required volumes of petroleum products, valuable contiguous components and new products based on them.

Table 3

Content of metals in oils

\begin{tabular}{|l|c|c|c|c|}
\hline \multirow{2}{*}{ Metal } & \multicolumn{4}{|c|}{ Content of metal, mg/kg } \\
\cline { 2 - 5 } & Sample 1 & Sample 2 & Sample 3 & Sample 4 \\
\hline Iron & 21.26 & 291.67 & 1.21 & 41.35 \\
\hline Zinc & 1.37 & 42.86 & 61.78 & 4.21 \\
\hline Nickel & 52.94 & 81.42 & 140.84 & 10.9 \\
\hline Vanadium & 112.21 & 180.3 & 2.78 & 10.99 \\
\hline Vanadium/nickel & 2.12 & 2.21 & 0.23 & 1 \\
\hline Chrome & 0.08 & 0.21 & 12.21 & 0.22 \\
\hline Calcium & 7.45 & 10.11 & $<0.74$ & non determined \\
\hline Cobalt & $<0.61$ & $<1.87$ & $<0.29$ & 0.11 \\
\hline Molybdenum & $<0.19$ & $<0.31$ & 0.24 & 0.59 \\
\hline Copper & 0.11 & 0.60 & & \\
\hline
\end{tabular}

Table 4

Physico-chemical properties of oils

\begin{tabular}{|c|c|c|c|c|}
\hline Property & Sample 1 & Sample 2 & Sample 3 & Sample 4 \\
\hline Coking ability, $\%$ & 10.14 & 10.61 & $7.07 *$ & 1.5 \\
\hline Freezing point, $\mathrm{K}$ & 290 & 317 & 282 & 261 \\
\hline Content of water, $\%$ & 5.0 & 25.0 & 5.5 & 0.03 \\
\hline Content of chlorides, $\mathrm{mg} / \mathrm{dm}^{3}$ & 2890 & 5400 & 7351 & 8.2 \\
\hline Content of sulfuric acid resins, vol \% & 17.8 & 24.5 & 15.9 & 14.6 \\
\hline
\end{tabular}


The most important physico-chemical properties of investigated oils are represented in Table 4.

The ability of the petroleum product to form coke during heating to high temperature without access to oxygen is an indicator of the raw materials quality for coking plants and the production of carbon black. The coking ability of all investigated samples is extremely high. The freezing point, which indicates the content of resinousasphaltenic hydrocarbons, is high too. This will cause difficulties in transporting oil, especially at low temperatures, and will require additional measures to reduce the freezing point. Sample 4 does not have this disadvantage.

The content of chlorides and water of investigated samples is also extremely high since these products did not undergo desalinization and dehydration processes, which are mandatory prior to oil refining. However, taking into account the high content of resinousasphaltenic hydrocarbons, such oil is extremely difficult to be dehydrated [25].

On average, the kinematic viscosity of most oils does not exceed $(5-25) \cdot 10^{-6} \mathrm{~m}^{2} / \mathrm{s}$ at $293 \mathrm{~K}$. The following technological parameters are determined and calculated with relation to viscosity: oil mobility in the reservoir during its extraction, the rate of filtration in the reservoir, the type of displacement agent, the pump suction capacity, the conditions for transportation along the oil pipeline, etc. Due to the oil viscosity, it is possible to roughly evaluate its composition. The main regularity is an increase in viscosity with increasing molecular weight of the fractions. The heavier the oil, the more amount of heavy fractions in its composition and the higher its viscosity. Thus, highly viscous oil contains a large amount of resinous-asphaltenic compounds, which complicates the processing of such oil. The dependence of oil viscosity on temperature is very important for the refining technology (pumping, heat exchange, settling, etc.), as well as for the application of petroleum products (drains, pumping, filtration, lubrication of friction surfaces, etc.). We determined the kinematic viscosity at atmospheric pressure within the temperature range of 293-368 K (Fig. 2).

It should be noted that regarding the kinematic viscosity, oils of the Yablunivsky deposit are somewhat unique. At $293 \mathrm{~K}$, the value is one hundred and two hundred times greater than the kinematic viscosity of the oil mixture of East-Ukrainian deposit $\left(9.45 \cdot 10^{-6} \mathrm{~m}^{2} / \mathrm{s}\right.$ at $293 \mathrm{~K}$ and $4.53 \cdot 10^{-6} \mathrm{~m}^{2} / \mathrm{s}$ at $323 \mathrm{~K}$, not represented in Fig. 2).

For Samples 1 and 2 a sharp increase in viscosity is observed within 293-323 K. The viscosity for Sample 1 is increased by 6.5 times, and for Sample 3 - by 3.6 times. Oil from the well 94 (Sample 2) is extra viscous and even in narrow temperature range (343-323 K) its viscosity decreases by 3.8 times.

The dynamic viscosity was determined within 293 $343 \mathrm{~K}$ varying the shear rates from 0.06 to $452 \mathrm{~s}^{-1}$. The results obtained at the share rate of $21 \mathrm{~s}^{-1}$ are represented in Fig. 3.

The significant difficulties may occur when pumping oils, since at $293 \mathrm{~K}$ the dynamic viscosity for Sample 1 is more than $3000 \mathrm{mPa} \cdot \mathrm{s}$, for Sample 2 - more than $62000 \mathrm{mPa} \cdot \mathrm{s}$ and for Sample $3-2770 \mathrm{mPa} \cdot \mathrm{s}$. It is evident that Samples 1 and 2 can not be pumped at the temperatures below $303 \mathrm{~K}$, and Sample 3 - at the temperatures below $338 \mathrm{~K}$. Since viscosity is a variable value and significantly depends on the shear stress, the investigated oils of Yablunivsky deposit have properties of a dilatant non-Newtonian liquid of the $1^{\text {st }}$ grade [26]. It should be noted that the rheological properties of heavy oils with high content of resinous-asphaltenic hydrocarbons are somewhat different from the properties of paraffinic oils [27-29].

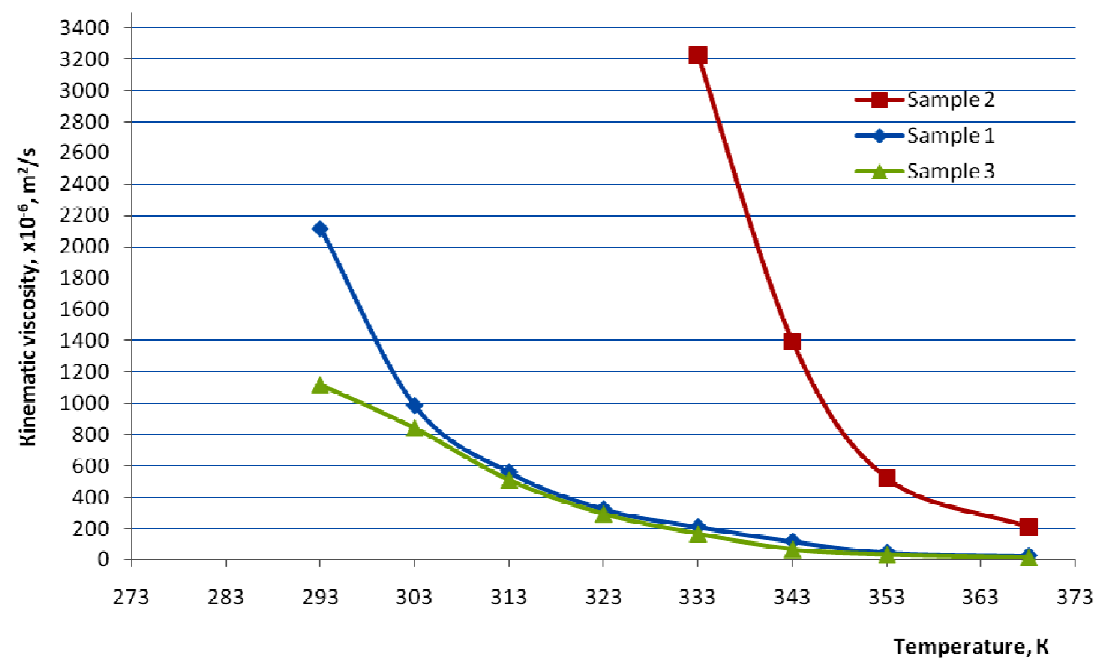

Fig. 2. Kinematic viscosity of Samples 1-3 vs. temperature 


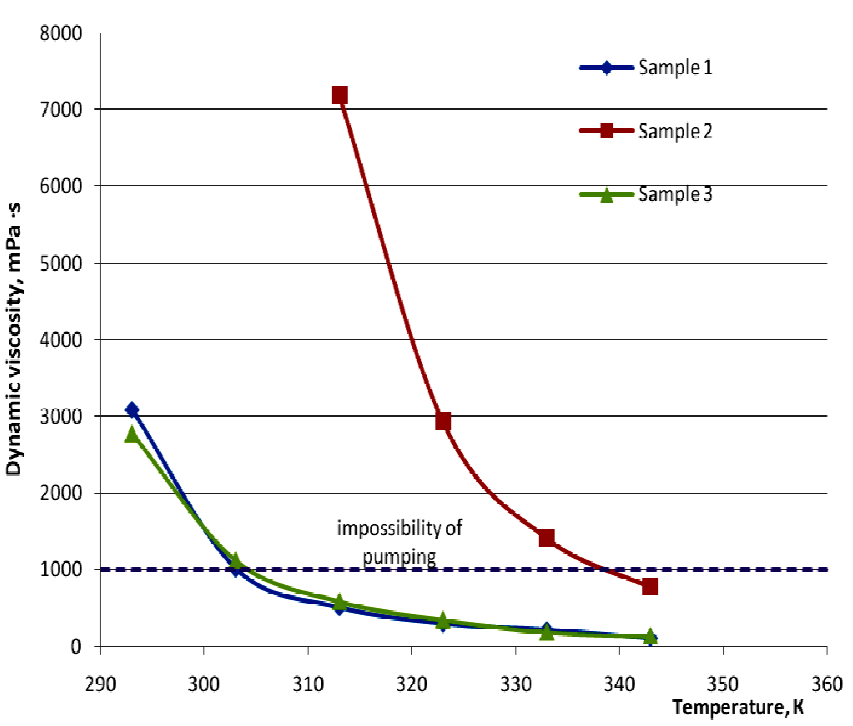

Fig. 3. Dynamic viscosity of Samples 1-3 vs. temperature at shear rate of $21 \mathrm{~s}^{-1}$

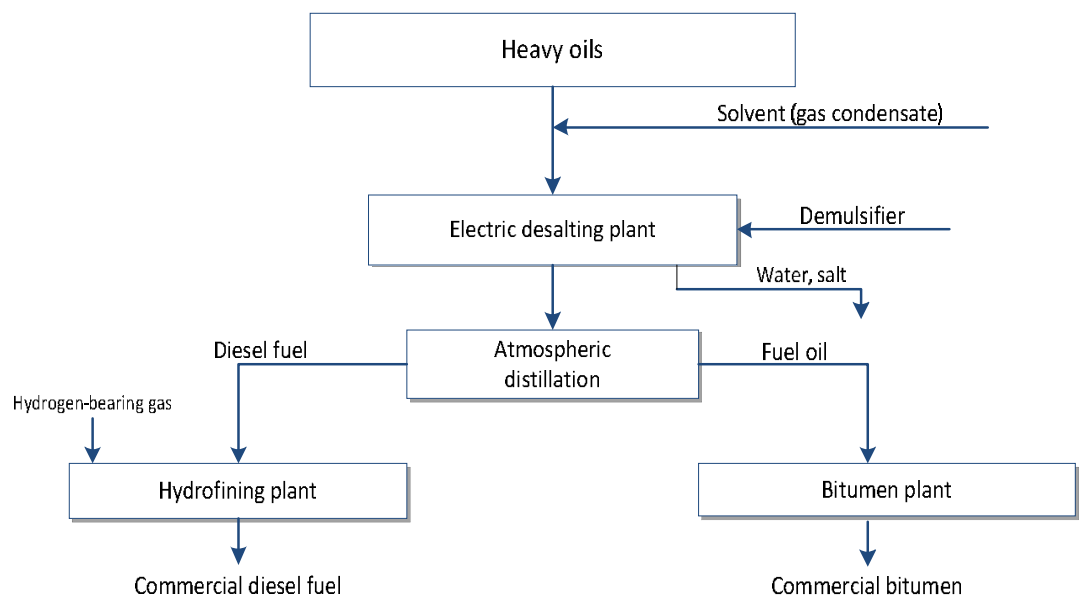

Fig. 4. Flow chart of heavy oils processing

Based on the physico-chemical properties of the investigated oils, we propose the following technological solutions for the further processing of heavy high sulfur oils (Fig. 4):

- the solvent (gas condensate) should be added before the electric desalting plant to reduce oil viscosity and facilitate further processing;

- primary oil refining must be carried out at the atmospheric distillation unit. Since there are no gases and gasoline fractions, and the yield of diesel fractions is low, the resulting products will be only diesel fraction and fuel oil with a high freezing point. Since fuel oil contains a significant amount of sulfur compounds, bitumen produced from such oil will have high adhesion properties;

- the diesel fuel fraction can serve as a raw material for the pyrolysis plant to produce ethylene and propylene, or may be sent to a hydrofining plant to produce a commercial diesel fuel;

- fuel oil is processed at the bitumen plant to produce a commercial bitumen.

\section{Conclusions}

Oils of the Yablunivsky deposit (Poltava region, Ukraine) were investigated and classified as extra heavy oils with the density of $>950 \mathrm{~kg} / \mathrm{m}^{3}$. The sulfur content in oils is high (about $3 \%$ ). There is a large amount of metals in the oils, all of them are of vanadium-type $(\mathrm{V} / \mathrm{Ni}>1)$. Oils are characterized by the high freezing point $(282$ $317 \mathrm{~K})$ and abnormally high kinematic viscosity $\left(2120 \cdot 10^{-6}\right.$ and $1123 \cdot 10^{-6} \mathrm{~m}^{2} / \mathrm{s}$ at $293 \mathrm{~K}$; and $4861 \cdot 10^{-6} \mathrm{~m}^{2} / \mathrm{s}$ at $323 \mathrm{~K})$. The studied oils exhibit the properties of dilatant 
non-Newtonian fluids of the $1^{\text {st }}$ grade. Extraction, dehydration, and primary processing of such oils are possible only when diluting them with gas condensate or straight-line light fractions. The general scheme of processing requires more detailed scientific work.

\section{References}

[1] World Oil Review, 2018.

https://www.eni.com/docs/en_IT/enicom/company/fuel-

cafe/WORLD-OIL-REVIEW-2018-Volume-1.pdf

[2] Baikov N.: Neftianoe Khoziatstvo, 2003, 4, 124.

[3] Gas, Water Injection Included in Off-Norway Heavy-Oil

Development: Oil\&Gas J., 2003, 101, 50.

[4] Bratychak M., Gunka V.: Khimia Nafty i Gazu. Vyd-vo Lviv Polytechnic, Lviv 2017.

[5] Tarasiuk V.: Beregynia 777, Sova, 2014, 2, 121.

https://cyberleninka.ru/article/v/vysokovyazkie-nefti-i-prirodnye-

bitumy-problemy-i-povyshenie-effektivnosti-razvedki-i-razrabotkimestorozhdeniy

[6] Antoniadi D., Valuiskiy A., Garushev A.: Neftianoe Khoziastvo, 1999, 1, 16.

[7] Zadymova N., Skvortsova Z., Traskin V. et al.: Colloid J., 2016, 78, 735 https://doi.org/10.1134/S1061933X16060211

[8] Shestopalov V., Gozhyk P., Lukin O.: ZN.UA, 2009, 775.

https://dt.ua/ECONOMICS/potuzhniy_vuglevodneviy_potentsial_n adr_ukrayini_osnova_priydeshnoyi_energetichnoyi_nezalezhnosti. html

[9] ASTM D1298-12b Standard Test Method for Density, Relative Density, or API Gravity of Crude Petroleum and Liquid Petroleum Products by Hydrometer Method.

[10] ASTM D3230-13 Standard Test Method for Salts in Crude Oil (Electrometric Method).

[11] ASTM D95-13(2018) Standard Test Method for Water in Petroleum Products and Bituminous Materials by Distillation. [12] ASTM D4294-10 Standard Test Method for Sulfur in Petroleum and Petroleum Products by Energy Dispersive X-Ray Fluorescence Spectrometry.

[13] ASTM D974-93 (02e1) Standard Test Method for Acid and Base Number by Color-Indicator Titration.

[14] ASTM D2887 Standard Test Method for Boiling Range Distribution of Petroleum Fractions by Gas Chromatography.

[15] ASTM D5307-97 (Reapproved 2002)e1 Standard Test Method for Determination of Boiling Range Distribution of CrudePetroleum by Gas Chromatography.

[16] ASTM D6352-04e1 A Standard Test Method for Boiling Range Distribution of Petroleum Distillates in Boiling Range from 174 to $700^{\circ} \mathrm{C}$ by Gas Chromatography.
[17] Babatunde O., Boichenko S., Topilnytskyy P., Romanchuk V.: Chem. Chem. Technol., 2017, 11, 220.

https://doi.org/10.23939/chcht11.02.220

[18] Mehta B., Mehta M. (Eds.): Organic Chemistry, $2^{\text {nd }}$ edn. PHI Learning Private Ltd, Delhi 2015.

[19] Chen Y.-F., Pu W.-F. et al.: Energ. Fuel., 2018, 32, 12308. https://doi.org/10.1021/acs.energyfuels.8b03091

[20] EN ISO 3104:1996 Petroleum products - Transparent and opaque liquids - Determination of kinematic viscosity and calculation of dynamic viscosity.

[21] Olanrewaju A., Hasan S.,Abu-Zahra M.: Petrol. Sci. Technol., 2016, 34, 659. https://doi.org/10.1080/10916466.2016.1154870

[22] Bolonnyi V., Serediuk M.: Rozvidka ta Rozrobka Naftovykh ta Gazovykh Rodovysh, 2004, 4, 34.

[23] Tyshchenko V., Zanozina I., Babintseva M et al.:

Neftepererabotka i Neftekhimia, 2008, 4, 14.

[24] Topilnytskyy P., Romanchuk V., Yarmola T.: Chem. Chem. Technol., 2018, 12, 400. https://doi.org/10.23939/chcht12.03.400 $\lceil 25\rceil$ Topilnytskyy P., Romanchuk V., Boichenko S., Golych Y.: Chem. Chem. Technol., 2014, 8, 211.

https://doi.org/10.23939/chcht08.02.211

[26] Green D., Southard M.: Perry's Chemical Engineers'

Handbook, $9^{\text {th }}$ edn. McGraw Hill Education 2019.

[27] Pylypiv L.: Naftova Galuz Ukrainy, 2016, 6, 29.

[28] Mendes R., Vinay G., Ovarlez G., Coussot Ph.: J. Non-Newton. Fluid, 2015, 220, 77. https://doi.org/10.1016/j.jnnfm.2014.09.011 [29] Mendes R., Vinay G., Ovarlez G., Coussot Ph.: J. Soc. Reol. Jpn., 2015, 59, 703. https://doi.org/10.1122/1.4916531

Received: January 26, 2019 / Revised: February 20, 2019 / Accepted: June 25, 2019

\section{ОСОБЛИВОСТІ ТЕХНОЛОГІЇ ПЕРЕРОБЛЕННЯ ВАЖКИХ НАФТ З ВИСОКИМ ВМІСТОМ СІРКИ}

Анотація. Проведені дослідження нафт Яблунівського родовища (Полтавська обл., Україна) для вибору подальших иляхів їх перероблення. За допомогою методу імітованої дистиляції досліджено фракиійний склад. Визначені структурномеханічні властивості нафтопродуктів, вміст металів та елементний склад. Встановлено, щзо нафти є важскими 3 високим вмістом сірки, не містять світлих дистилятів, мають високу густину та в'язкість, велику кількість металів. Запропоновано блок-схему переробки таких нафт.

Ключові слова: важка нафта, фізико-хімічні властивості, реологічні властивості. 